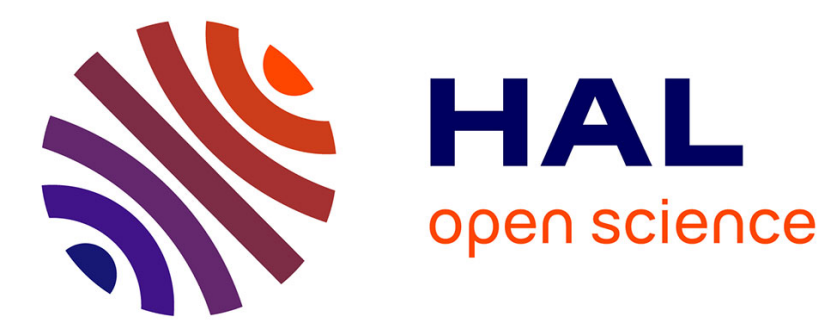

\title{
Histopathology of mussels ( sp.) from the Tamar estuary, UK
}

J.P Bignell, G.D Stentiford, N.G.H Taylor, B.P Lyons

\section{To cite this version:}

J.P Bignell, G.D Stentiford, N.G.H Taylor, B.P Lyons. Histopathology of mussels ( sp.) from the Tamar estuary, UK. Marine Environmental Research, 2011, 72 (1-2), pp.25. 10.1016/j.marenvres.2011.05.004 . hal-00720187

\section{HAL Id: hal-00720187 \\ https://hal.science/hal-00720187}

Submitted on 24 Jul 2012

HAL is a multi-disciplinary open access archive for the deposit and dissemination of scientific research documents, whether they are published or not. The documents may come from teaching and research institutions in France or abroad, or from public or private research centers.
L'archive ouverte pluridisciplinaire HAL, est destinée au dépôt et à la diffusion de documents scientifiques de niveau recherche, publiés ou non, émanant des établissements d'enseignement et de recherche français ou étrangers, des laboratoires publics ou privés. 


\section{Accepted Manuscript}

Title: Histopathology of mussels (Mytilus sp.) from the Tamar estuary, UK

Authors: J.P Bignell, G.D Stentiford, N.G.H Taylor, B.P Lyons

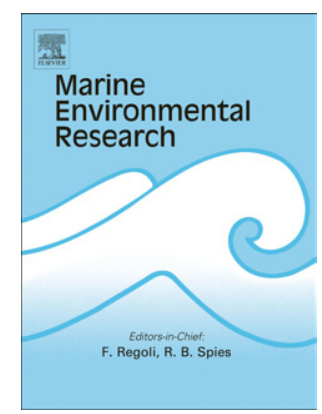

PII:

S0141-1136(11)00054-7

DOI:

10.1016/j.marenvres.2011.05.004

Reference:

MERE 3527

To appear in: Marine Environmental Research

Received Date: 4 September 2009

Revised Date: 28 March 2011

Accepted Date: 23 May 2011

Please cite this article as: Bignell, J.P, Stentiford, G.D, Taylor, N.G.H, Lyons, B.P. Histopathology of mussels (Mytilus sp.) from the Tamar estuary, UK, Marine Environmental Research (2011), doi: 10.1016/j.marenvres.2011.05.004

This is a PDF file of an unedited manuscript that has been accepted for publication. As a service to our customers we are providing this early version of the manuscript. The manuscript will undergo copyediting, typesetting, and review of the resulting proof before it is published in its final form. Please note that during the production process errors may be discovered which could affect the content, and all legal disclaimers that apply to the journal pertain. 
1 Histopathology of mussels (Mytilus sp.) from the Tamar estuary, UK.

2

3

5

6

7

8

9

a Centre for Environment, Fisheries and Aquaculture Science (Cefas), Barrack Road,

Bignell, J.P. ${ }^{a}$, Stentiford, G.D. ${ }^{a}$, Taylor, N.G.H. ${ }^{a}$, Lyons, B.P. ${ }^{a *}$

*Address for correspondence

Weymouth, Dorset DT4 8UB, United Kingdom.

10

Tel: $+44(0) 1305206600$

11

Fax: +44 (0) 1305206601

12

13

14

15

16

17

18

19

20

21

brett.lyons@cefas.co.uk

23

24

Running title: Histopathology of mussels

25

26 
1

2

3

4

5

6

\section{Abstract}

This study assessed numerous histological parameters as markers of health status in mussels (Mytilus spp.) collected from several locations along a contamination gradient on the River Tamar and two coastal sites on the north and south coast of Cornwall, UK. Twentyseven health parameters were assessed including the presence of pathogens, inflammatory lesions, non-specific pathologies and reproductive condition. Logistic regression showed that reproductive condition and inflammatory lesions showed changes indicative of a contamination gradient response. Mussel populations further upstream within the Tamar were relatively less developed compared to mussels situated downstream in the estuary. Compared to coastal locations, mussels sampled within the Tamar also exhibited a higher prevalence of inflammatory lesions that increased at locations situated furthest upstream. Similarly, levels of lipofuscin within the kidney epithelium were highest in mussels sampled within the estuary and Whitsand Bay compared to Trebarwith Strand. The most prevalent pathogens observed during this survey included Rickettsia/Chlamydia-like organisms (R/CLO), gill ciliates including Ancistrum mytili, the copepod Mytilicola intestinalis, Ciliophoralike organisms and Marteilia sp. Marteilia sp. was observed in $31 \%$ of the mussels sampled from the Cremyll Ferry site. Generally, the range and prevalence of pathogens was highest from the two estuarine locations at Cremyll Ferry and Wilcove. No significant differences were observed between estuarine sampling sites and Whitsand Bay with respect to median epithelial cell height of digestive tubules, however mussels from Trebarwith Strand did exhibit a reduced median epithelial cell height compared to mussels sampled from other sampling sites. Species genotyping was also undertaken during this study in order to consider any histological differences in relation to species. Results are discussed in relation to histopathology health parameters and biological effects monitoring.

Keywords: Histopathology, biological effects, Mytilus edulis, Mytilus galloprovincialis, hybrids, diseases, mussels, species. 
1

2

3

\section{Introduction}

Inventory-based chemical monitoring programmes are restricted to the identification of a limited range of contaminants and provide little or no information on their biological significance. Accordingly, increasing emphasis is being placed on determining the causal relationships between contaminant exposure and observable biological effects in aquatic organisms (Thain et al., 2008). It is known that exposure to contaminants are significant stressors for some species, especially in estuaries, and while environmental quality standards in UK marine waters are generally being met they do not take into consideration the effects of chronic exposure to complex mixtures of contaminants (Matthiessen et al., 1993). As such, the identification of fish and shellfish diseases and pathologies, with a broad range of aetiologies, is increasingly being used as indicators of environmental stress since they provide a definite and ecologically-relevant biological end-point of chronic contaminant exposure (Matthiessen et al., 1993; Mix, 1988; Stentiford et al., 2009). Additionally, the application of histological biomarkers provides an effective set of tools for detecting and characterising the biological end points of toxicant exposure (Hinton et al., 1992). Histological lesions have been used as sensitive and reliable indicators to determine the health status of aquatic species in a wide range of studies (Auffret 1988; Stentiford et al., 2009).

Mussels (Mytilus spp) have shown considerable potential as sentinel organisms in studies monitoring the health status of aquatic systems. They are generally abundant, sessile and exhibit a range of biological responses when stressed or exposed to environmental contaminants (Goldberg et al., 1978; Moore et al., 1987; Livingstone and Pipe, 1992; Widdows and Donkin, 1992; Brooks et al., 2009). The application of histopathology to mussels can incorporate measures of reproductive and metabolic condition, and allows for the detection of a range of pathogens that may affect morbidity and mortality. Furthermore, mussel histopathology has been previously employed to investigate the casual relationships between environmental health and exposure to contaminants (Lowe and Pipe, 1987; Auffret, 1988; Marigómez et al., 2006; Bignell et al., 2008). As such, a plethora of histopathological criteria can be utilised in monitoring programmes using mussels. 
Here we report prevalence data for a range of pathologies and pathogens present in populations of Mytilus spp. collected from the Tamar Estuary, UK and from coastal sites in the South West of England (see Shaw et al.; in this issue). This study was part of an integrated workshop investigating the health status of the Tamar Estuary using a suite of chemical, cellular and whole organism endpoints.

\section{Material and methods}

\section{1. Sampling}

As part of the sampling protocol, samples were obtained for analysis of biochemistry, heavy metals, histochemistry, toxicogenomics and biomarker response (Money et al.; Shaw et al., in this issue). Further samples were also obtained for histopathology. Mussels were collected from four sampling sites in and around the Tamar Estuary, South West England (Neal Point, Wilcove, Cremyll Ferry, Whitsand Bay). Samples were also collected from another coastal site (Trebarwith Strand) on the north coast of Cornwall, UK (Figure 1).

For histopathological analysis of health status, 30 mussels were collected from the waterline at low tide on all sampling occasions during May 2006. Shells were opened by severance of the adductor muscle followed by removal of the tissue mass. Samples of gill were taken, snap frozen in liquid nitrogen and subsequently processed for species identification as described below. A 3-4mm cross section was removed along a standard plane allowing for all major organs and tissues (gill, mantle, kidney, digestive gland, gonad and byssus gland/foot) to be incorporated into a single histological section. Excised tissues were placed into histological cassettes and immediately placed into Davidson's seawater fixative. Fixation was allowed to proceed for $24 \mathrm{~h}$ before being transferred into $70 \%$ industrial methylated spirit (IMS). Samples were transported to the Cefas, Weymouth laboratory for subsequent histological processing and analysis. Samples were processed in a Vision Bio-Systems Peloris vacuum infiltration processor followed by embedding in paraffin wax. Sections $(3-5 \mu \mathrm{m})$ were obtained using a rotary microtome and subsequently stained with haematoxylin and eosin. Sections 
1 were evaluated "blind" for sex and a number of health index parameters. Assessment of 2 adipogranular tissue was carried out using a qualitative index (as described by Bignell et al., 32008 ) based on a score of 1-5 to indicate the 'absent', 'present', 'scattered', 'frequent' or 'abundant' status of this cell type respectively. Gonadal development staging was carried out as described by Seed (1976). Epithelial cell height and kidney lipofuscin were measured using an index as described in Table 1. All micrographs were captured using a Nikon DXM1200F digital video camera and the Lim Screen Measurement ${ }^{\mathrm{TM}}$ Lucia G image capture system (Nikon, UK).

\section{2. Species Identification}

Mytilus populations around the South West of England are known to comprise of both $M$. edulis and M. galloprovincialis, along with hybrids of both species. In order to consider the effect of species on the histological health parameters recorded, individual mussels were genotyped as previously described (Bignell et al., 2008). Briefly, Total DNA was extracted from gill tissue using DNAzol reagent according to the manufacturers recommended protocol (Invitrogen, UK). The resulting pellet was suspended in $100 \mu \mathrm{l}$ of molecular grade water. Species identification was undertaken using previously published PCR primer pairs Me15 5'CCAGTATACAAACCTGTGAAGA-3' and Me16 5'-TGTTGTCTTAATAGGTTTGTAAGA-3' for the Glu gene (Inoue et al., 1995). Species-specific products are formed with $M$. edulis and $M$. galloprovincialis producing $180 \mathrm{bp}$ and $126 \mathrm{bp}$ amplification products respectively, with hybrids producing both bands. PCR was performed in a $50 \mu \mathrm{l}$ reaction volume consisting of $1 \mathrm{x}$ GoTaq® flexi buffer containing $2.5 \mu \mathrm{l}$ template $2.5 \mathrm{mM} \mathrm{MgCl} 2,1 \mathrm{mM}$ dNTPs mix, 100 pmol of sense and anti-sense primers, 2.5 units of Go Taq polymerase (Promega, UK). The reaction mix was overlaid with mineral oil and after pre-heating to $95^{\circ} \mathrm{C}$ for $5 \mathrm{~min}$, subjected to 35 temperature cycles of: $1 \mathrm{~min}$ at $95^{\circ} \mathrm{C}, 1 \mathrm{~min}$ at $55^{\circ} \mathrm{C}$ and $1 \mathrm{~min}$ at $72^{\circ} \mathrm{C}$ followed by a final extension step of $10 \mathrm{~min}$ at $72^{\circ} \mathrm{C}$. Twenty $\mu \mathrm{l}$ of amplified products were electrophoresed in a 4 $\%(w / v)$ agarose/TAE (40 mM Tris-acetate, pH7.2, $1 \mathrm{mM}$ EDTA) gel containing $1.0 \mu \mathrm{g} / \mathrm{ml}$ ethidium bromide, and visualised under UV irradiation.

\subsection{Statistical analysis}


1 Cross-tables and logistic regression were used to look for associations between the presence

2 of different parasites, sampling location and the occurrence of the following dependent

3 variables: inflammation, brown cell inflammation and high gonadal status. Due to low cell counts in the cross-tables and for ease of interpretation, indices for gonadal status were simplified into two categories; immature and developing/ripe for the purpose of logistic regression analysis. All analysis was conducted in R v.2.7.0 ( $R$ Development Core Team 2008). Models were built using a backward stepwise approach by first fitting the maximal model and then systematically removing the least significant factors until only significant factors remained.

\section{Results}

Thirty mussels were sampled from each site and examined for twenty seven health index parameters including reproductive markers, non-specific pathologies, pathologies of the digestive diverticula and infectious diseases (Table 2). Representative micrographs of pathologies within these categories are presented in Figures 2 and 3.

\subsection{Reproductive markers}

When present, ADG cells were situated in the vesicular connective tissue. These cells stained bright pink with eosin and in some cases, were granular in appearance. The median ADG rate was lowest in mussels collected from Whitsand Bay (0.0) and Cremyll Ferry (0.5). Mussels collected from Neal Point, Wilcove and Trebarwith Strand had a higher ADG rate in comparison (2.0, 2.0 and 2.0 respectively). The median ADG rate of mussels collected from Whitsand Bay and Cremyll Ferry was lower than in mussels collected from Trebarwith Strand, Neal Point and Wilcove. The median gonadal stage was lowest in mussels collected from Neal Point (2.0) and Wilcove (2.0). The median gonadal stage was highest in mussels collected from Cremyll Ferry (3.5), Whitsand Bay (4.0) and Trebarwith Strand (3.0). Logistic regression demonstrated that gonadal development was significantly better in sites downstream of Neal Point (Table 3). 
1 The prevalence of atresia (females only) was within the range of $59-100 \%$ (Table 2) although

2 severity of the condition was not recorded. Four individual female mussels from both Cremyll

3 Ferry and Wilcove exhibited apoptosis in the germinal epithelium of the ovarian follicles. This pathology has previously been confirmed by Cefas as apoptosis through a combination of morphology and the terminal deoxynucleotide transferase mediated deoxy-UTP nick-end labelling (TUNEL) assay.

\subsection{Non-specific pathology}

Three types of inflammatory lesion were observed within the numerous tissues and organs examined (Table 2). Inflammatory pathologies were most prevalent in mussels collected from the estuarine sampling sites. General inflammation was characterised by the presence of haemocyte infiltration of the vesicular connective tissue (VCT) in and around the digestive diverticula. Inflammation was observed as either focal (Fig. 1a) or diffuse lesions and was most prevalent in mussels from Neal Point $(56.7 \%)$, Wilcove (50 \%) and Cremyll Ferry (20 $\%)$. One individual exhibited extensive inflammation throughout the majority the gonadal ducts. Brown cell (BC) inflammation consisting of small haemocytic aggregates (Fig.1b) was observed mostly within the VCT. These aggregates could also be seen in the gills, gonadal follicles, stomach wall and the epithelia of the digestive diverticula. BC inflammation within the VCT was most prevalent at Cremyll Ferry (50.0\%), Wilcove (33.3) and Neal Point (26.7 \%). However, BC inflammation within the gonadal follicles was most prevalent at Neal Point (43.3 $\%)$, Wilcove (16.7 \%) and Cremyll Ferry (10.0\%). BC inflammation of the gills was observed at relatively low prevalence from all sites with the highest prevalence being observed in mussels sampled from Wilcove $(16.7 \%)$. Pearl formations were observed at low prevalence from all sampling locations (<6.7\%). No granulocytoma were observed during this study. Logistic regression showed that both the prevalence of haemocyte infiltration and $B C$ inflammation significantly decreased further downstream from Neal Point (Table 3).

Pathology of the digestive diverticula was measured in terms of reduced epithelial cell height and prevalence of digestive tubule degeneration. Epithelial cell height was determined using a simple index (Table 1). Mussels sampled from the Trebarwith Strand coastal site exhibited the 
1 highest median epithelial cell height index thus indicating a lower epithelial thickness. Neal

2 Point, Whitsand Bay, Wilcove and Cremyll Ferry mussels showed no differences between

3 each other sharing a median epithelial cell height index of 1 . Disintegration of the digestive tubules was observed as either partial or complete and was often difficult to distinguish between classic degeneration per se, or poor preservation resulting from inadequate fixation. There were signs of poor tissue preservation as demonstrated by loss of cellular structure and poorly defined cytoplasm and nuclei. In many cases there was loss of the apical region of digestive cells situated within the digestive tubule epithelium. Extreme cases often resulted in complete loss of the digestive epithelium. The highest recorded prevalence of this degeneration was recorded in mussels sampled from the two coastal sampling sites of Trebarwith Strand (97.0\%) and Whitsand Bay (53.0\%). The prevalence of degeneration from the remaining estuarine sites was $33.3 \%, 33.3 \%$ and $13.3 \%$ at Cremyll Ferry, Neal Point and Wilcove respectively.

Lipofuscin accumulation was identified by a "yellow-brown" to "reddish-brown" colouration (see Stevens and Chalk; 1996) within the kidney epithelium (Fig. 1f). Here small particles of pigment could be observed of low colour intensity. Enlarged lipofuscin accumulations that were more intense in colour could also be seen within some epithelial cells. This was measured using a Kidney Lipofuscin (KL) index (Table 2). The median $\mathrm{KL}$ index at the Trebarwith strand coastal site was 0 with all remaining sites showing a score of 1 .

\subsection{Pathogens}

Five different pathogens were detected during this study. Mussels from Cremyll Ferry had the most prevalent and widest array of pathogens. The most significant finding was of the paramyxian, Marteilia sp., characterised by distinctive eosinophilic cell-within-cell sporocysts situated within the epithelium of the digestive diverticula (Fig. 2a). This parasite was observed in $31.0 \%$ of mussels sampled from Cremyll Ferry. Hypertrophy of the digestive tubules was observed in those individuals harbouring a heavy infection. Marteilia sp. was also observed in mussels from Wilcove at a prevalence of $6.9 \%$. The most prevalent parasite overall was Mytilicola intestinalis (Fig. 2b). The intestinal copepod was observed attached to the stomach 
1 wall in mussels sampled from Cremyll Ferry (55.2\%), Neal Point (33.3\%), Wilcove (23.3\%)

2 and Whitsand Bay (10.0\%). Ancistrum mytili (Fig. 2c) and other gill ciliates were observed in

3 mussels collected from all estuarine sites with those from Cremyll Ferry exhibiting the highest prevalence $(26.7 \%)$. Ciliophora-like organisms (Fig. 2d) were seen infecting the digestive epithelial cells (Fig. 2e) of mussels from Cremyll Ferry (25.0\%), Whitsand Bay (16.7\%) and Wilcove $(3.3 \%)$. Other intracellular pathogens of the digestive epithelium were Rickettsia/Chlamydia-like organisms (R/CLO). Inclusion bodies were observed infecting mussels from Cremyll Ferry (11.1\%) and Whitsand bay (3.3\%). Of those pathogens observed, Marteilia sp. was the only pathogen that appeared to elicit a host response as demonstrated by inflammation and a reduction in ADG tissue.

\subsection{Species identification}

The species composition of the five sampling locations examined during this study differed between sites and included the presence of Mytilus edulis, Mytilus galloprovincialis and hybrids. All sites consisted of mixed species populations except for Cremyll Ferry, which consisted solely of $M$. edulis. The species breakdown for each sampling site was as follows (figures in parenthesis refer to percentage of M. edulis, M. galloprovincialis and hybrids respectively): Trebarwith Strand (0, 97, 3), Whitsand Bay $(37,7,56)$, Neal Point $(93,0,7)$, Wilcove $(93.3,3.3,3.3)$, Cremyll Ferry $(100,0,0)$.

\section{Discussion}

This study presents baseline histological data for twenty-seven health index parameters of mussels (Mytilus edulis, Mytilus galloprovincialis and their hybrids) sampled from several locations within the Tamar estuary and from two coastal sites. Histopathology lends itself well to the collection of data pertinent to health status as it provides a snapshot of health at the time of sampling. The data generated is helpful in providing complementary information to support additional cellular and biochemical based biomarker techniques such as those used in this monitoring programme (Money et al.; Shaw et al., in this issue). Hence, the use of histopathology can help to dissociate markers of underlying health or condition from those associated with exposure to contaminants (see Stentiford et al., 2009). Similarly, it is also 
1 important to consider the effects of disease. Numerous microscopic lesions observed in 2 mussels such as inflammation and atresia, have previously been linked to a chemical

3 aetiology. However, a number of discrete pathogens, identified using histopathology can exhibit characteristics that are similar in appearance to toxicopathic lesions. Consequently, it

is also important to consider the effects of disease and not simply the potential effects of contaminants in isolation.

\section{1 Health index parameters}

The histological assessment of storage reserve cells (including ADG tissue) contained within the mantle tissue of mussels is a marker that has been used extensively in biological effects monitoring programmes using mussels. Together with the vesicular connective tissue (VCT) cells, ADG cells are the primary energy reserves for fuelling gametogenesis and byssus production (Lowe and Pipe, 1987; de Zwaan and Mathieu, 1992). During the warmer summer months, mussels actively feed and store energy for the commencement of gametogenesis during autumn and winter. As gametogenesis progresses, there is a subsequent reduction in levels of glycogen and a concomitant reduction in the frequency and size of energy storage cells (Seed, 1969); most notably the ADG cells. Eventually the mantle is full of ripe gametes with little or no storage cells present. Following spawning (spring/early summer) this annual cycle is ready to repeat once more. Depending on gametogenic condition, population location or species composition, relative proportions of storage tissues to germinal cells may vary, but typically follow an annual cycle. Taking these into consideration, it is generally understood that deviations from a normal state, particularly with respect to a reduction in ADG tissue, can be used as an indicator of contaminant exposure and physiological stress (Lowe and Pipe, 1987).

In this study, mussels sampled from sites further downstream in the Tamar exhibited relatively more developed gonads as demonstrated by median gonadal index and logistical regression analysis. Interestingly this supports biochemical and histochemical data which indicated relatively higher impact at sites further upstream within the Tamar compared to those closer to the mouth of the estuary (Shaw et al., in this issue). Studies have shown that exposure to 
1 organic contaminants and metals result in suppressed gamete development, inhibition of 2 gonadal follicle development and/or enhancement of gamete atresia in mussels (Lowe and $3 \quad$ Pipe, 1987; Kluytmans et al., 1988; Livingstone and Pipe, 1992). It is difficult to interpret the

differences seen in this study with respect to atresia although one might speculate that chemical insult within the estuary is a contributing factor. However, with mussels from Trebarwith Strand exhibiting a similar prevalence of atresia and relatively lower concentrations of metals and polycyclic aromatic hydrocarbons (PAHs), it is clear that numerous factors could be involved. The development of qualitative indices similar to those used for other health index parameters used in this study could help to better interpret this kind of data in future studies. Similarly, it is difficult to decipher the cause of apoptosis within this study, especially due to the relatively low number of mussels affected (four individuals per site). Elsewhere, studies in fish have noted casual links between contaminant exposure and gonadal apoptosis. Marty et al (1997) showed that exposure to crude oil resulted in increased gonadal apoptosis in Pink salmon (Oncorhynchus gorbuscha) larvae whilst Lyons et al (2004) noted spermatagonial apoptosis of the viviparous blenny (Zoarces viviparus). Despite our findings, none of the mussel populations examined appeared adversely compromised with respect to their reproductive function since relatively healthy median levels of maturing gonadal tissue were observed.

Conversely to gonadal index, the median ADG rate decreased downstream with mussels from Cremyll Ferry and Whitsand Bay exhibiting the lowest median ADG index with fewer ADG cells of decreased cytoplasmic volume present. This decreasing trend of ADG rate could be indicative of the normal reproductive cycle. With that being said, mussels sampled from Cremyll Ferry exhibited the widest range and highest prevalence of pathogens observed within this study. The majority of the pathogens reported here do not elicit a significant host response with the exception of Marteilia sp. Where observed, those individuals infected with Marteilia sp. had little or no ADG tissue present. Therefore, the relatively high prevalence of Marteilia sp. (31.0\%) coupled with the pathology associated with this parasite, might also be a contributing factor to the relative decrease in the median ADG rate observed at Cremyll Ferry. 
1 Since its initial reporting in mussels from UK waters (Bignell et al., 2008), this is the highest

2 recorded prevalence of Marteilia sp. within UK waters.

3

Inflammatory lesions are often observed in aquatic organisms including mussels sampled from stressful environments including estuaries and are commonly associated with exposure to metals and organic xenobiotics (Sunila, 1986; Auffret, 1988), and pathogens (Rasmussen, 1986; Lowe \& Moore, 1979). Following an inflammatory response, it would appear that BC inflammatory aggregates migrate through the VCT to a suitable basement membrane of a target organ for removal from the mussel via diapedesis. This is evident by the observation of BC inflammatory aggregates within organs (and their epithelia) including the stomach, intestine, digestive diverticula, gonad and kidney. Logistic regression showed no significant associations between inflammatory and parasites prevalence. This could indicate (a) the presence an unidentified bacterial or viral infection or (b) elevated levels of other stressors, such as salinity and contaminants, at the Tamar sampling sites. Mussels sampled from the sites within the Tamar not only had the highest prevalence of inflammatory lesions, but also displayed a general increase in prevalence further upstream towards Neal Point (with the exception of brown cell (BC) inflammation of the VCT). However, when we combined all BC inflammation data together, irrespective of tissue location, logistic regression showed a significant increase the closer to Neal Point. This indicated that the prevalence of the major inflammatory lesions seen in this study decrease towards the mouth of the estuary.

Numerous studies have focused on the digestive diverticula as a target organ for measuring abnormal changes relating to chemical exposure. These include atrophy of the digestive tubules, an increase in the basophil cell complement, increased lipid accumulation within digestive epithelial cells as well as measurements of lysosomal stability (Lowe et al., 1981; Lowe \& Clarke, 1989; Lowe \& Pipe, 1994). In this study we observed degeneration of the digestive tubules in many of the mussels examined. Degeneration of the digestive tubules has previously been linked to toxicity (Lowe and Clarke, 1989, Rasmussen, 1980), however it is interesting that those sampled from Trebarwith Strand exhibited the highest prevalence of tubule disintegration (Table 2). Dimitriadis and Koukouzika (2003) previously showed that 
1 disintegration of the digestive tubules, including poorly defined apical cell line and cytoplasmic

2 content within the tubule lumen, can occur as little as 2 hours following removal from

3 seawater. Although care was taken to standardise sampling of animals from all field sites, it is possible that the increased distance of Trebarwith Strand from the laboratory where dissection and fixation of specimens occurred may have contributed to the phenomenon.

Previous studies have demonstrated lipofuscin accumulation within pathologically altered lysosomes of epithelial cells of the digestive diverticula following exposure to xenobiotics (Moore et al., 1987; Lowe \& Clark, 1989). We investigated lipofuscin accumulation within lysosomes situated in the kidney epithelium, which were observed and recorded in using a qualitative index (Table.1). The kidney is an important organ for the excretion of unmetabolised metals and is rich in tertiary lysosomes containing metal-binding lipofuscin (Livingstone \& Pipe, 1992). These lysosomes are subsequently excreted in the urine following exocytosis. It is commonplace to observe relatively low levels of lipofuscin-containing lysosomes within the kidney epithelium. Although no gradient response was observed between the estuarine sampling sites, those within the Tamar and from Whitsand Bay shared a median kidney lipofuscin $(\mathrm{KL})$ index of ' 1 ' compared to mussels sampled from Trebarwith Strand that had a median KL index of ' 0 '. This result supports those observations of Shaw et al. (in this issue) who concluded that levels of metals in mussels within the Tamar estuary and at Whitsand Bay were an order of magnitude higher than baseline levels for the UK. Furthermore, levels of metals at Trebarwith Strand were between one and two orders of magnitude lower than sampling sites situated in the Tamar.

\subsection{Effect of species}

Few studies have investigated the effects of species on measurements such as parasitic infection, metal accumulation, contaminant related protein expression, and pathology (Lobel et al., 1990; Coustau et al., 1991; López et al., 2002; Bignell et al., 2008). In this study genotyping was carried out on individual mussels in order to (a) determine the species distribution of mussels sampled from the estuarine and coastal sampling sites and (b) take into consideration any potential data variation that may be attributed to species differences. It 
1 is noteworthy that the majority of mussels sampled in this study were $M$. edulis. However,

$297 \%$ of mussels sampled from the coastal site of Trebarwith Strand were M. galloprovincialis.

3 This confirms the work of Skibinski et al. (1982) and Hilbish et al. (2002) that extensively characterised the south western hybrid zone in the UK. Despite species being determined for all individual mussels, no species differences regarding histopathology could be investigated due to insufficient numbers of individual "species" at each of the sampling sites. Although no differences were detected here, studies have previously shown that the reproductive cycle and pathology may differ significantly between different mussel species collected from the same location and at the same time (Bignell et al., 2008; Secor et al., 2001). Whether the hybrid complex of mussel species collected as part of this study can affect biomarker response or contaminant bioaccumulation remains to be shown and as such could be a target of future studies where mussels from hybrid populations are to be used to assess environmental status.

\section{Conclusions}

Histopathology has been used extensively for the investigation of health in aquatic organisms and is complementary to other techniques used in biological effects programmes. The aim of this study was to undertake a histopathology survey of mussels from the River Tamar, surrounding area and at an additional coastal site, in the context of biological effects monitoring. Several of the histological health index parameters used here confirm the findings of Shaw et al. (this issue), demonstrating that sites situated in the upper part of the Tamar estuary were relatively more impacted when compared with those closer to the coast. Future studies incorporating mussel histopathology should at least consider the use of these parameters including gonadal and adipogranular index, inflammatory lesions and kidney lipofuscin (KL). It is also recommended that other histological criteria such as those measured in relation to the digestive diverticula, are also included wherever possible if target organs of interest are available.

During this study, we experienced an artefact (degeneration of the digestive diverticula) that was potentially linked to air exposure or inadequate tissue preservation. Nonetheless, with 
1 mussels becoming commonplace in programmes that monitor the biological effects of

2 contaminants, it is timely to consider quality assurance in the manner in which mussels are

3 sampled for mussel histopathology and other biological effects. Particularly in national programmes that encompass sites over a large geographical area. Integrated programmes that measure the biological effects of contaminants are becoming more commonplace therefore this will surely benefit all those techniques that are utilised. Similar guidelines are already in place for estuarine and offshore monitoring programmes utilising flatfish (Feist et al., 2004). In this respect, International Council for Exploration of the Seas (ICES) guidelines for conducting histopathology on mussels have been initiated through the ICES Working Group on the Biological Effects of Contaminants (WGBEC). It is also essential that grading criteria for histological health parameters are developed and validated for use in environmental monitoring programmes, Their development, along with appropriate AQC protocols will strengthen the use of mussels as biomonitoring organisms and facilitate their inclusion in International programmes, classifying the ecological health status of aquatic ecosystems, such as the Water Framework Directive and the new EU Marine Strategy Framework Directive (Haggar et al., 2008; Thain et al., 2008).

\section{Acknowledgments}

The authors wish to thank Plymouth Marine Laboratory staff for assisting with the sampling collection programme. This project was funded by the Department for Environment Food and Rural Affairs (Defra) Contract No. AE1136 (PREDICT 2).

\section{References}

Auffret, M., 1988. Histopathological changes related to chemical contamination in Mytilus edulis from field and experimental conditions. Marine Ecology Progress Series 46, 101-107. 
1 Bignell, J.P., Dodge, M.J., Feist, S.W., Lyons, B., Martin, P.D., Taylor, N.G.H., Stone, D.,

2 Travalent, L., Stentiford., G.D., 2008. Mussel histopathology: effects of season, disease and

3 species. Aquatic Biology 2, 1-15.

4

5

Brooks, S., Lyons, B., Goodsir, F., Bignell, J., Thain, J., 2009. Biomarker responses in mussels, an integrated approach to biological effects measurements. Journal of Toxicology and Environmental Health - Part A: Current Issues 72 (3-4), 196-208.

Coustau, C., Renaud, F., Maillard, C., Pasteur, N., Delay, B., 1991. Differential susceptibility to a trematode parasite among genotypes of the Mytilus edulis / galloprovincialis complex. Genetic Research 57, 207-212.

de Zwaan, A., Mathieu, M., 1992. Cellular Biochemistry and Endocrinology, in: Gosling, E., The mussel Mytilus: Ecology, physiology, genetics and culture. Elsevier, Amsterdam, pp. 223308.

Dimitriadis, V.K., Koukouzika, N., 2003. Effect of sampling procedures, transportation stress and laboratory maintenance on the structure and function of the digestive gland epithelium of the mussel Mytilus galloprovincialis. Marine Biology 142, 915-924.

Feist, S.W., Lang, T., Stentiford, G.D., Köhler, A., 2004. Use of liver pathology of the European flatfish dab (Limanda limanda L.)and flounder (Platichthys flesus L.) for monitoring. ICES Techniques in Marine Environmental Sciences. 38, 1-42.

Goldberg, E.D., Bowen, V.T., Farrington, J.W., Harvey, G., Martin, J.H., Parker, P.L., Risebrough, R.W., Robertson, W., Schneider, E., Gamble, E., 1978. The Mussel Watch Environmental Conservation 5 (2), 101-125. 
1 Hagger, J.A., Jones, M.B., Lowe, D., Leonard, P.D.R., Owen, R., Galloway, T.S., 2008.

2 Application of biomarkers for improving risk assessments of chemicals under the Water

3 Framework Directive: A case study. Marine Pollution Bulletin 56, 1111-1118.

4

5

Hilbish, T.J., Carson, E.W., Plante, J.R., Weaver, L.A., Gilg, M.R., 2002. Distribution of Mytilus edulis, M. galloprovincialis, and their hybrids in open-coast populations of mussels in southwestern England. Marine Biology 140, 137-142.

Hinton, D.E., Baumen, P.C., Gardener, G.C., Hawkins, W.E., Hendricks, J.D., Murchelano, R.A., Okhiro, M.S., 1992. Histopathological biomarkers, in: (Huggett, R.J., Kimerle, R.A., Mehrle, P.M., \& Bergman, H.L. eds, Biomarkers: biochemical, physiological and histological markers of anthropogenic stress. Lewis Publsihers, Ml. pp.155-210.

Kluytmans, J.H., Brands, F., Zandee, D.I., 1988. Interactions of Cadmium with the Reproductive Cycle of Mytilus edulis L. Marine Environmental Research 24, 189-192.

Livingstone, D.R., Pipe, R.K., 1992. Mussels and environmental contaminants: Molecular and cellular aspects, in: Gosling, E., The mussel Mytilus: Ecology, physiology, genetics and culture. Elsevier, Amsterdam, pp. 383-464.

Lobel, P.B., Belkhode, S.P., Jackson, S.E., Longerich, H.P., 1990. Recent taxonomic discoveries concerning the mussel Mytilus: Implications for biomonitoring. Archives of Environmental Contamination and Toxicology 19, 508-512.

López, J.L., Marina, A., Vázquez, J., Alvarez, G., 2002. A proteomic approach to the study of the marine mussels Mytilus edulis and M. galloprovincialis. Marine Biology 141, 217-223.

Lowe, D.M., Clarke, K.R., 1989. Contaminant-induced changes in the structure of the digestive epithelium of Mytilus edulis. Aquatic Toxicology 15, Issue 4, 345-358. 
1 Lowe, D.M., Moore, M.N., 1979. The cytology and occurrence of granulocytomas in mussels.

2 Marine Pollution Bulletin 10, 137-141.

3

4 213-226.

Lowe, D.M., Pipe, R.K., 1994. Contaminant induced lysosomal membrane damage in marine mussel digestive cells: an in vitro study Aquatic Toxicology 30, Issue 4, 357-365

Lyons, B.P., Bignell, J., Stentiford, G.D., Feist, S.W., 2004. The viviparous blenny (Zoarces viviparus) as a bioindicator of contaminant exposure: application of biomarkers of apoptosis and DNA damage. Marine Environmental Research 58, 757-761.

Marigómez, I., Soto, M., Cancio, I., Orbea, A., Garmendia, L., Cajaraville, M.P., 2006. Cell and tissue biomarkers in mussel, and histopathology in hake and anchovy from Bay of Biscay after the Prestige oil spill (Monitoring Campaign). Marine Pollution Bulletin 53, 287-304.

Marty, G.D., Short, J.W., Dambach, D.M., Willits, N.H., Heintz, R.A., Rice, S.D., Stegeman, J.J., Hinton, D.E., 1997. Ascites, premature emergence, increased gonadal cell apoptosis, and cytochrome P4501A induction in pink salmon larvae continuously exposed to oilcontaminated gravel during development. Canadian Journal of Zoology 75, 989-1007.

Matthiessen, P., Thain, J.E., Law, R.J., Fileman, T.W., 1993. Attempts to assess the environmental hazard posed by complex mixtures of organic chemicals in UK estuaries. Marine Pollution Bulletin 26, 90-95. 
2 Mix, M.C., 1988. Shellfish diseases in relation to toxic chemicals. Aquatic Toxicology, 11, 29-

3

4

5

42.

Moore, M.N., Livingstone, D.R., Widdows, J., Lowe, D.M., Pipe, R.K., 1987. Molecular, cellular and physiological effects of oil-derived hydrocarbons on molluscs and their use in impact assessment. Philosophical Transactions. Royal Society of London Series B. Biological Sciences 316, 603-623.

Rasmussen, L., 1980. Light microspocical studies of the acute toxic effects of $N$ nitrosodimethylamine on the marine mussel, Mytilus edulis. Journal of Invertebrate Pathology $39,66-80$.

Rasmussen, L.P.D., 1986. Virus-associated granulocytoma in the marine mussel Mytilus edulis, from three sites in Denmark. Journal of Invertebrate Pathology 48, 117-123.

R Development Core Team, 2008. R: A language and environment for statistical computing. R Foundation for Statistical Computing, Vienna, Austria. ISBN 3-900051-07-0, URL http://www.R-project.org.

Secor, C.L., Day, A.J., Hilbish, T.J. 2001. Factors influencing differential mortality within a marine mussel (Mytilus spp.) hybrid population in southwestern England: reproductive effort and parasitism. Marine Biology 138, 731-739.

de Zwaan, A., Mathieu, M., 1992. Cellular Biochemistry and Endocrinology. In: Gosling, E., The mussel Mytilus: Ecology, physiology, genetics and culture. Elsevier, Amsterdam, pp. 223308.

Seed R.,1976. Ecology. In: Bayne, B.L., Marine mussels, their ecology and physiology. International Biological Programme 10. Cambridge University Press, Cambridge, pp. 13-65. 
2 Skibinski, D.O.F., Beardmore, J.A., Cross, T.F., 1983. Aspects of the population genetics of

3 Mytilus (Mytilidae; Mollusca) in the British Isles. Biological Journal of the Linnean Society 19, $4 \quad 137-183$.

5

6 Stentiford, G.D., Bignell, J.P., Lyons, B.P., Feist, S.W., 2009. Site-specific disease profiles in fish and their use in environmental monitoring. Marine Ecology Progress Series 381, 1-15.

Stevens, A., Chalk, B.T., 1996. Pigments and minerals, in: Bancroft, J.D., Stevens, A., Theory and practice of histological techniques, Fourth edition, Churchill Livingstone, pp. 243-267.

Sunila, I., 1984. Copper- and cadmium- induced histological changes in the mantle of Mytilus edulis L. (Bivalvia). Limnologica 15 (2), 523-527.

Thain, J.E., Vethaak, A.D., Hylland, K., 2008. Contaminants in marine ecosystems: developing an integrated indicator framework using biological effects techniques. ICES Journal of Marine Science 65 (8), pp. 1508-1514.

Widdows, J., Donkin, P., 1992. Mussels and environmental contaminants: Bioaccumulation and physiological aspects, in: Gosling, E., The mussel Mytilus: Ecology, physiology, genetics 21 and culture. Elsevier, Amsterdam, pp. 383-464. 
- Reproductive condition and inflammation showed contamination gradient response.

- Estuarine locations exhibited increased prevalence of inflammatory lesions.

- Relatively higher occurrence of kidney lipofuscin from estuarine sites.

- Marteilia sp. observed in $31 \%$ of mussels sampled from Cremyll Ferry site. 


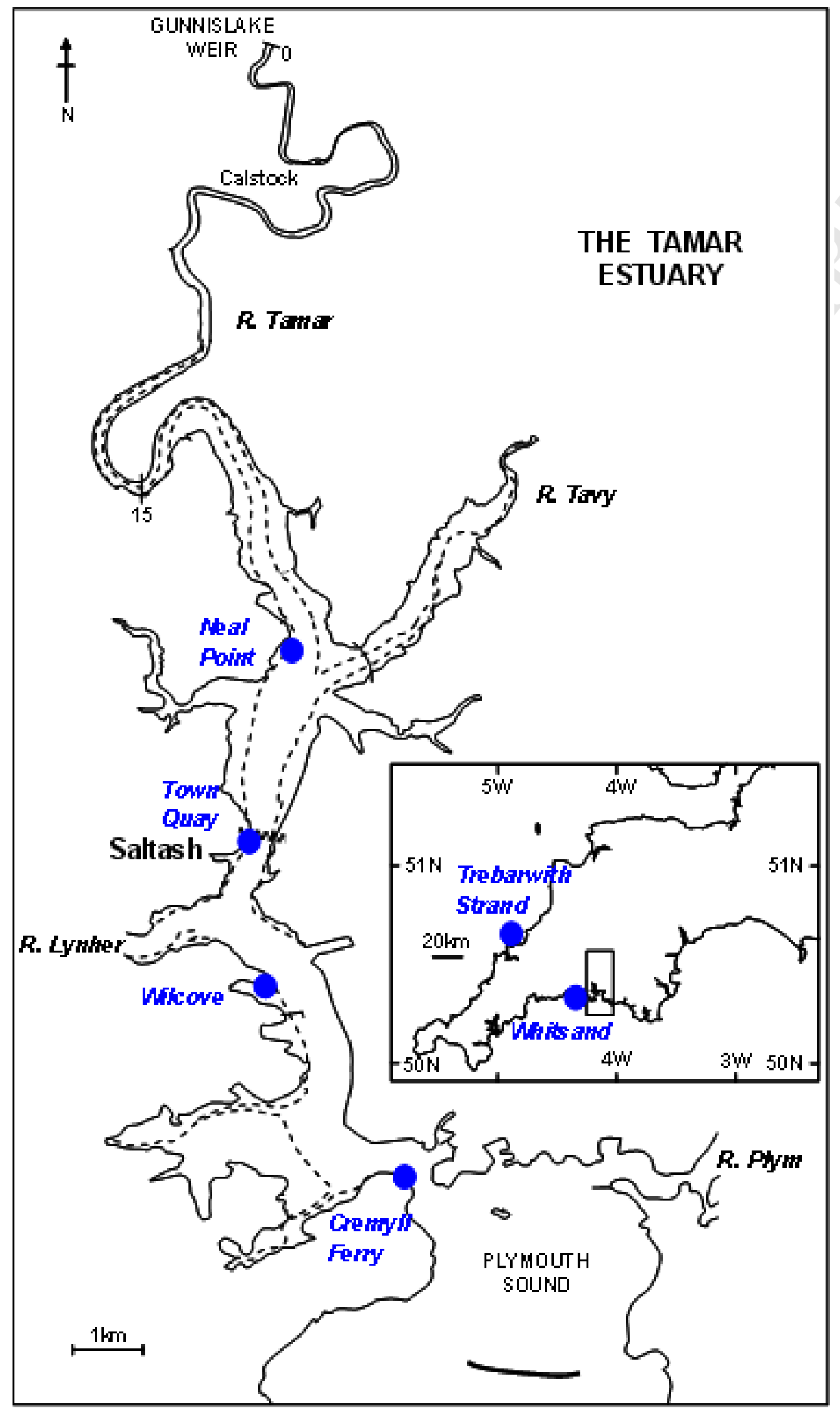




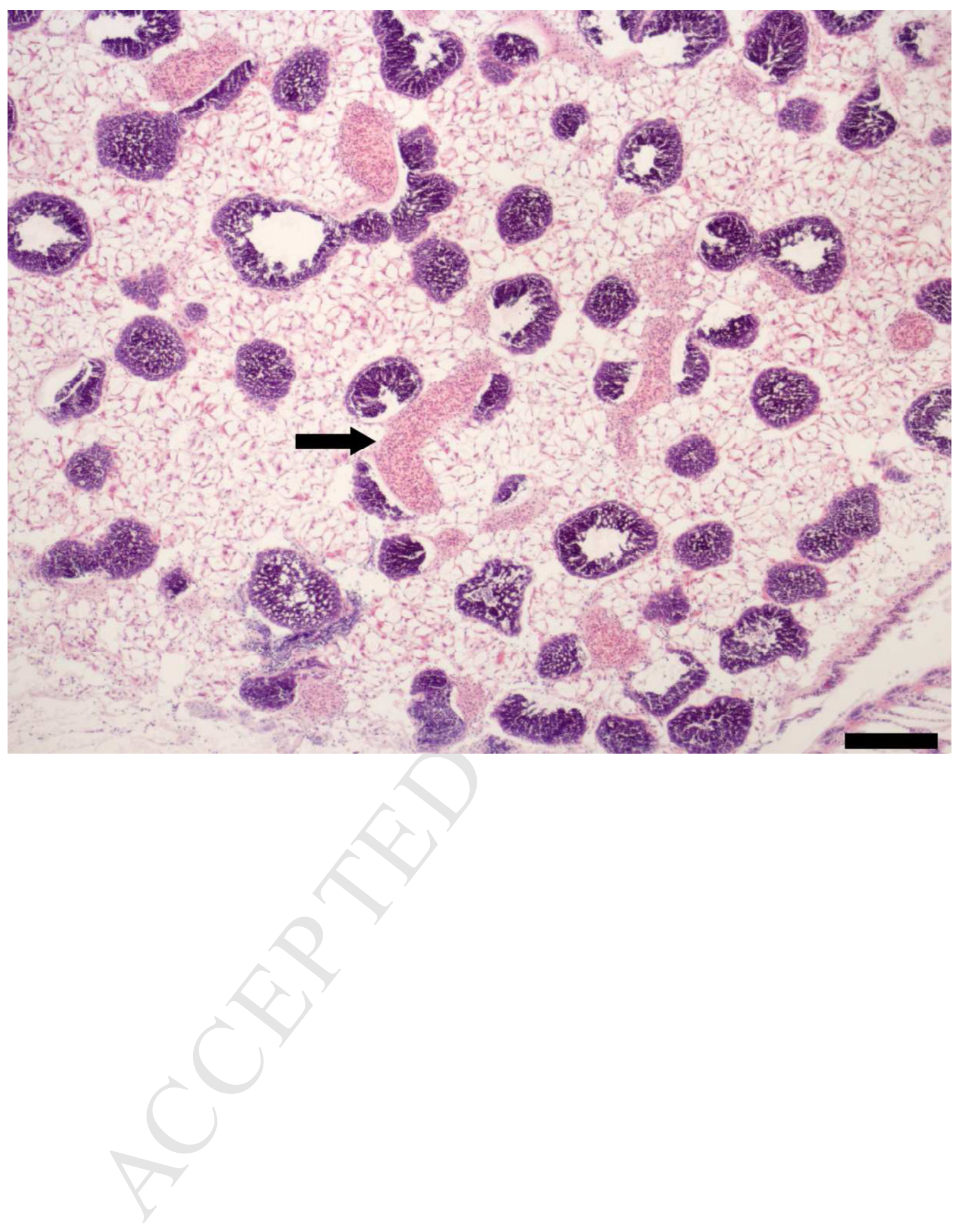




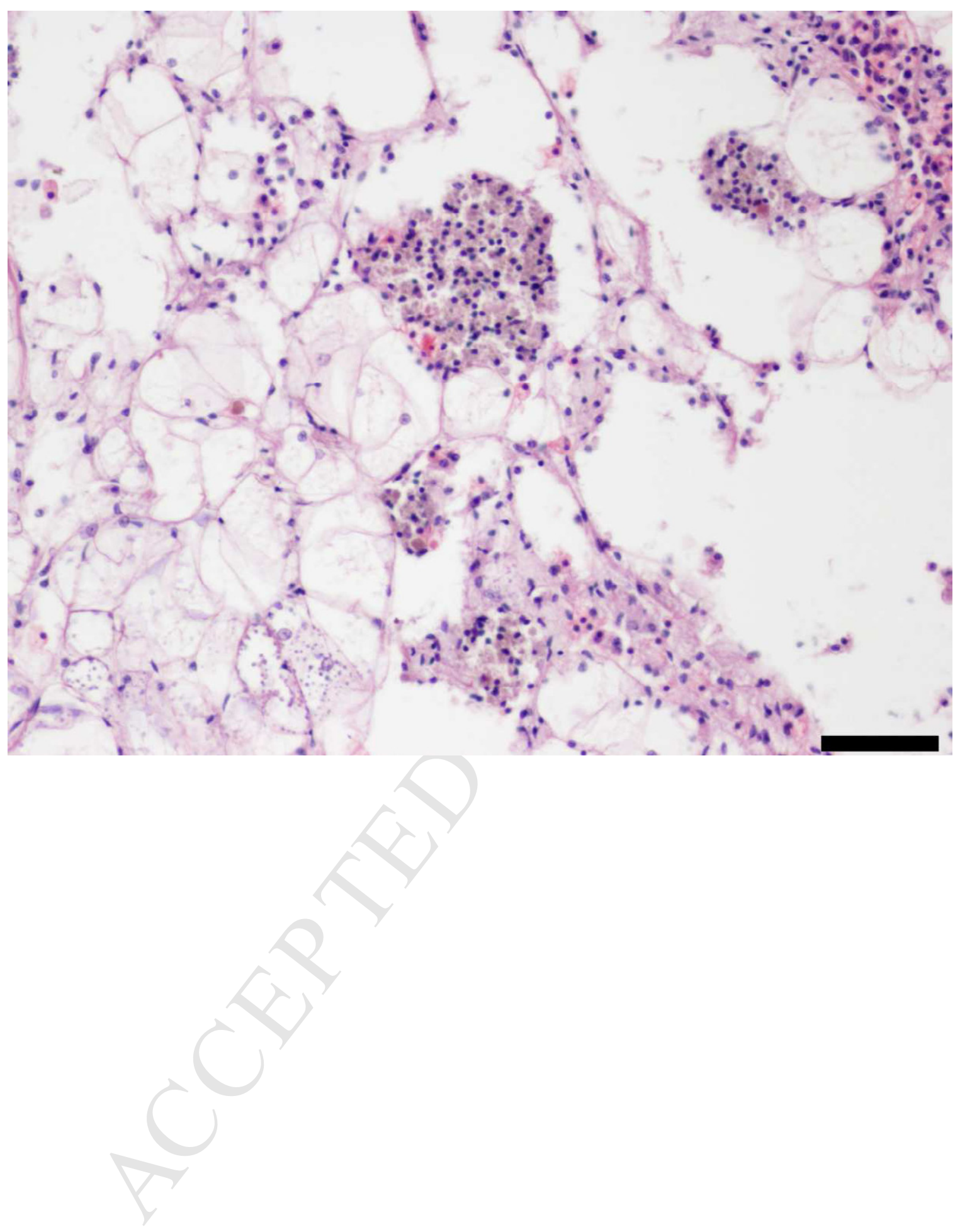




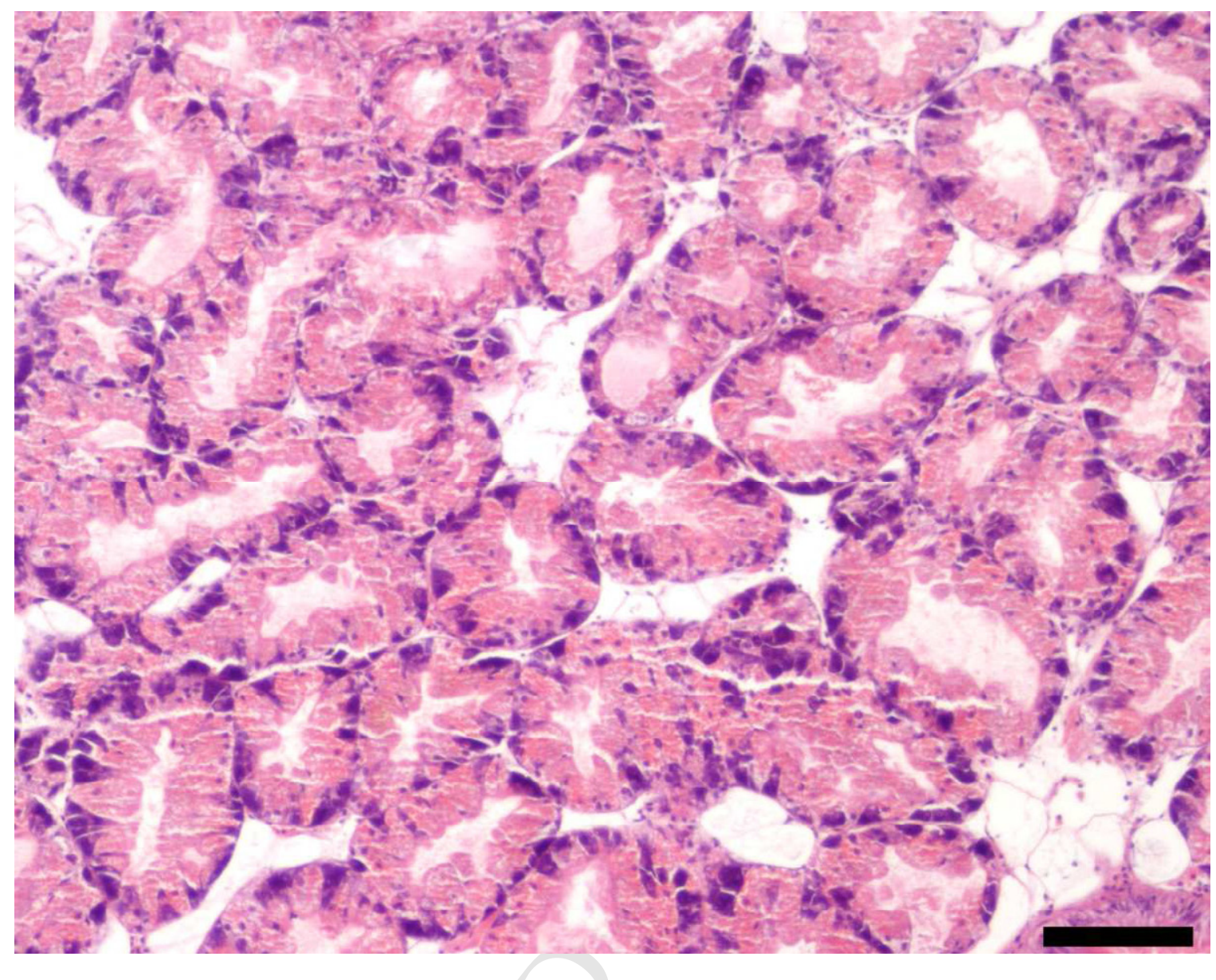




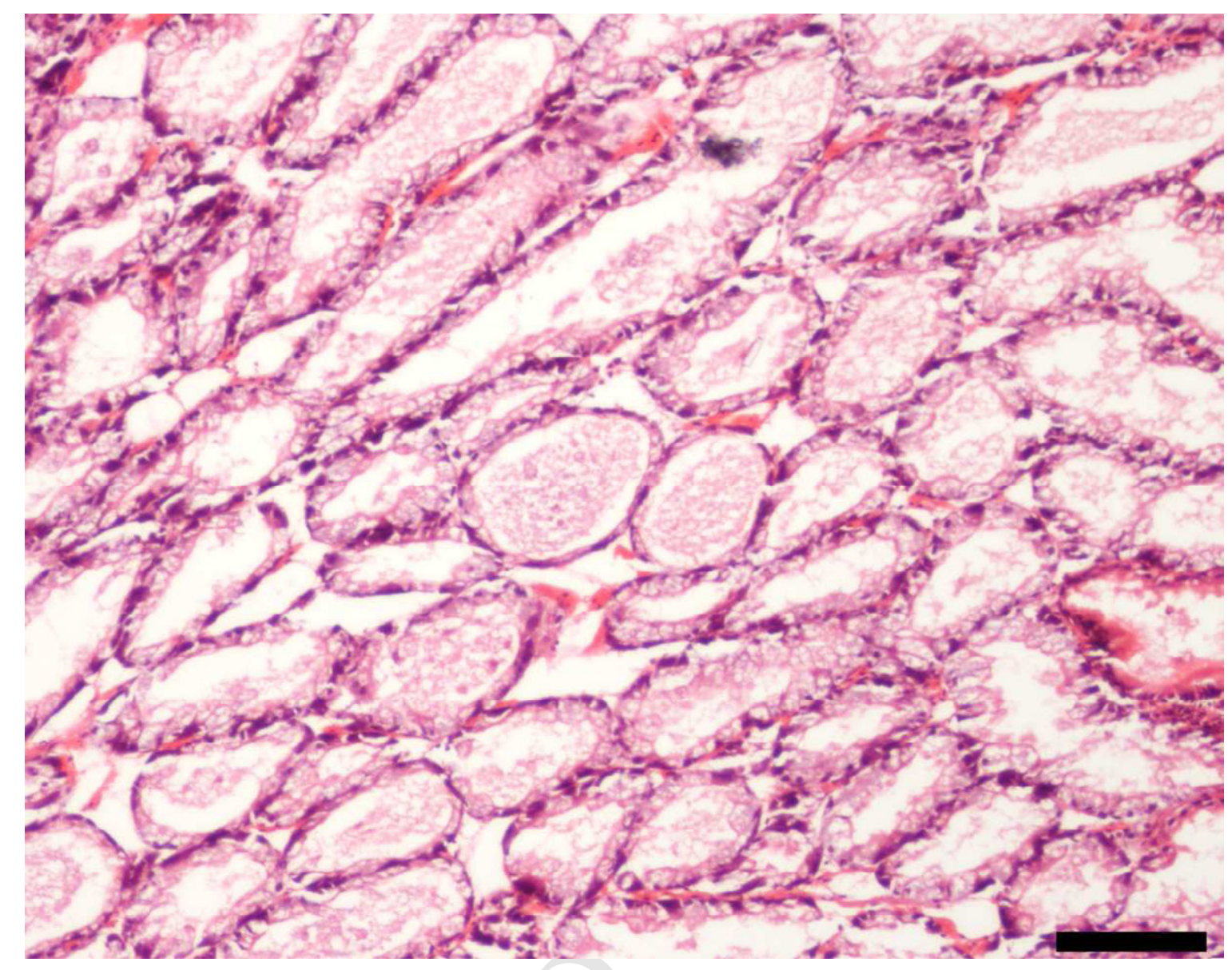




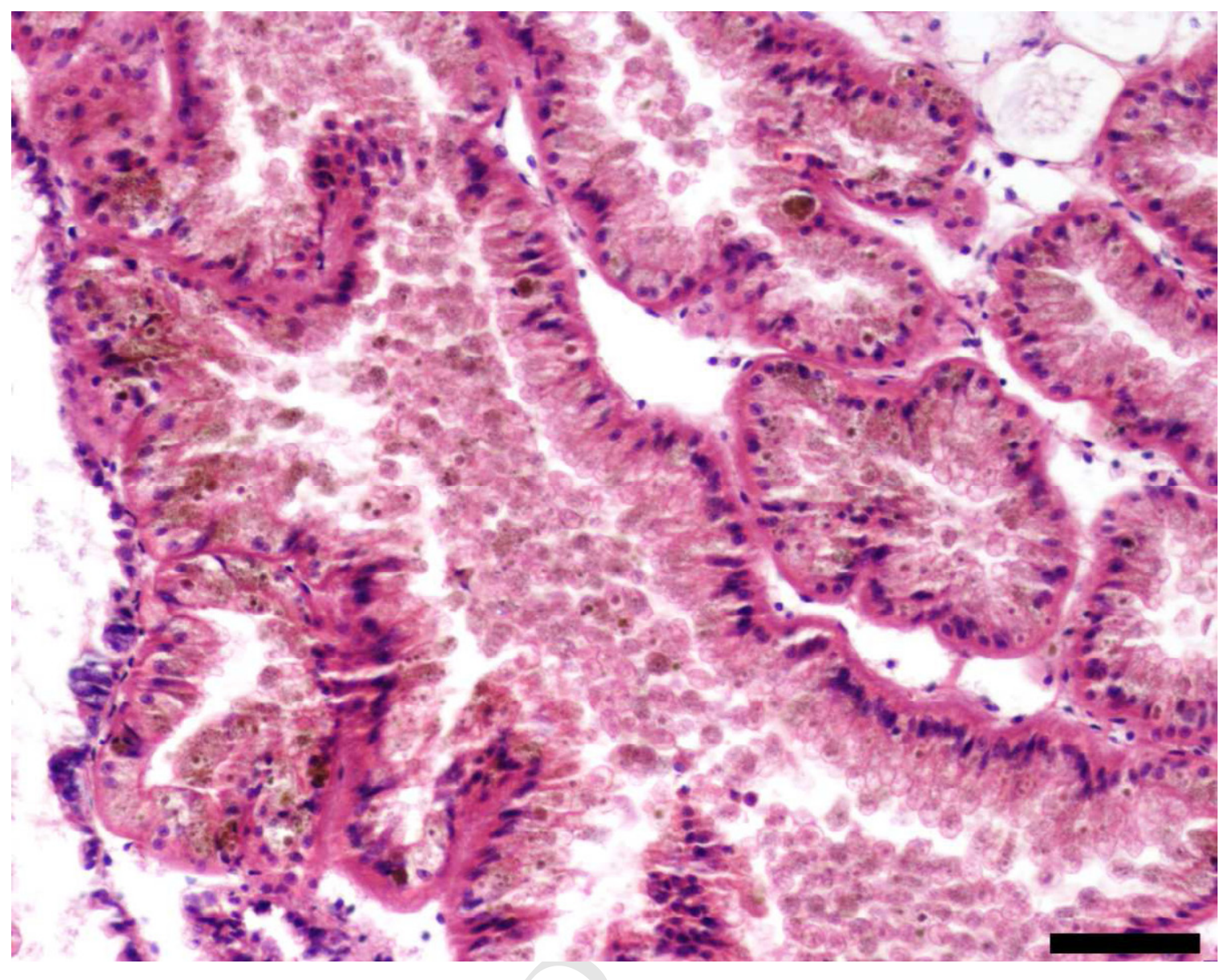




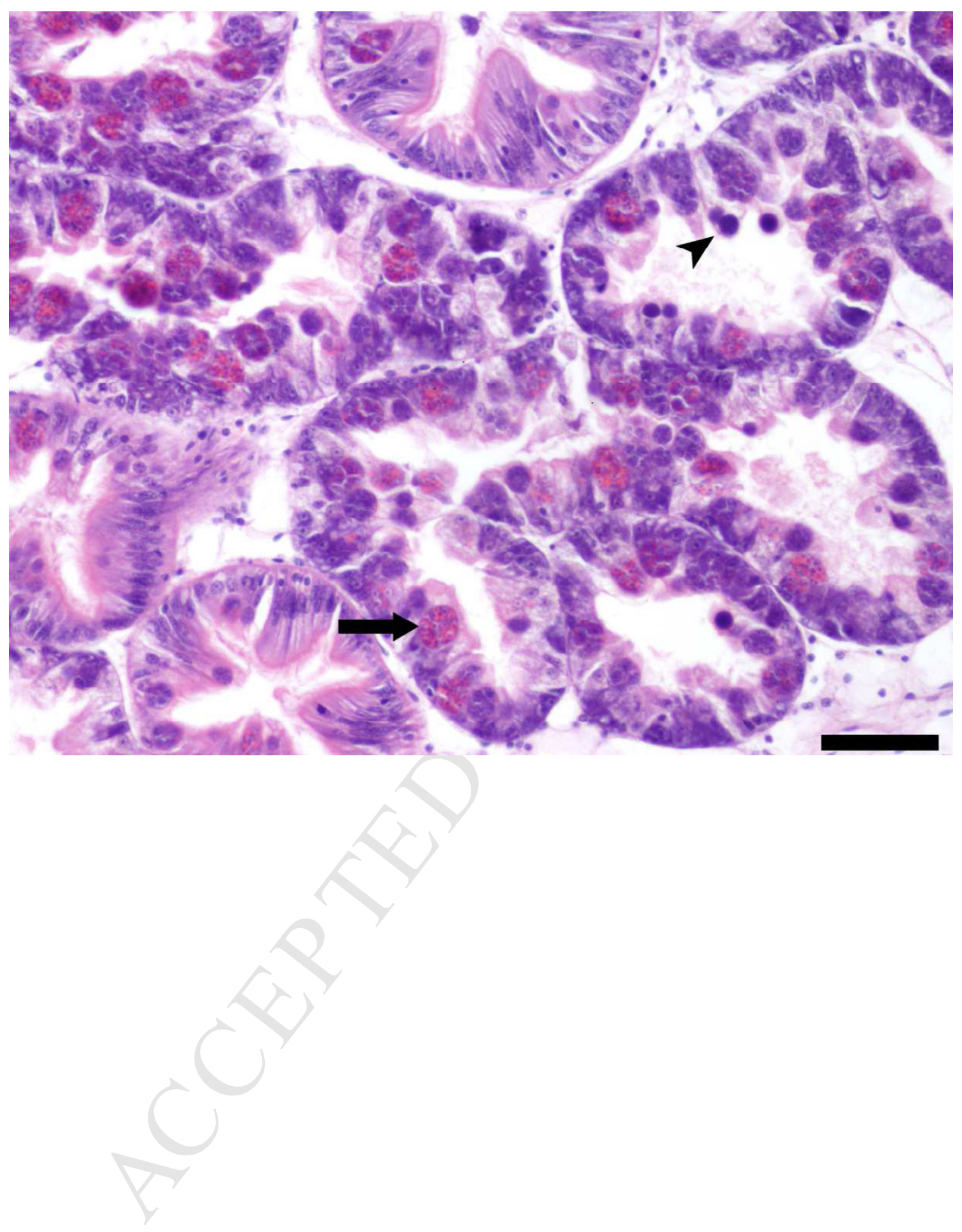




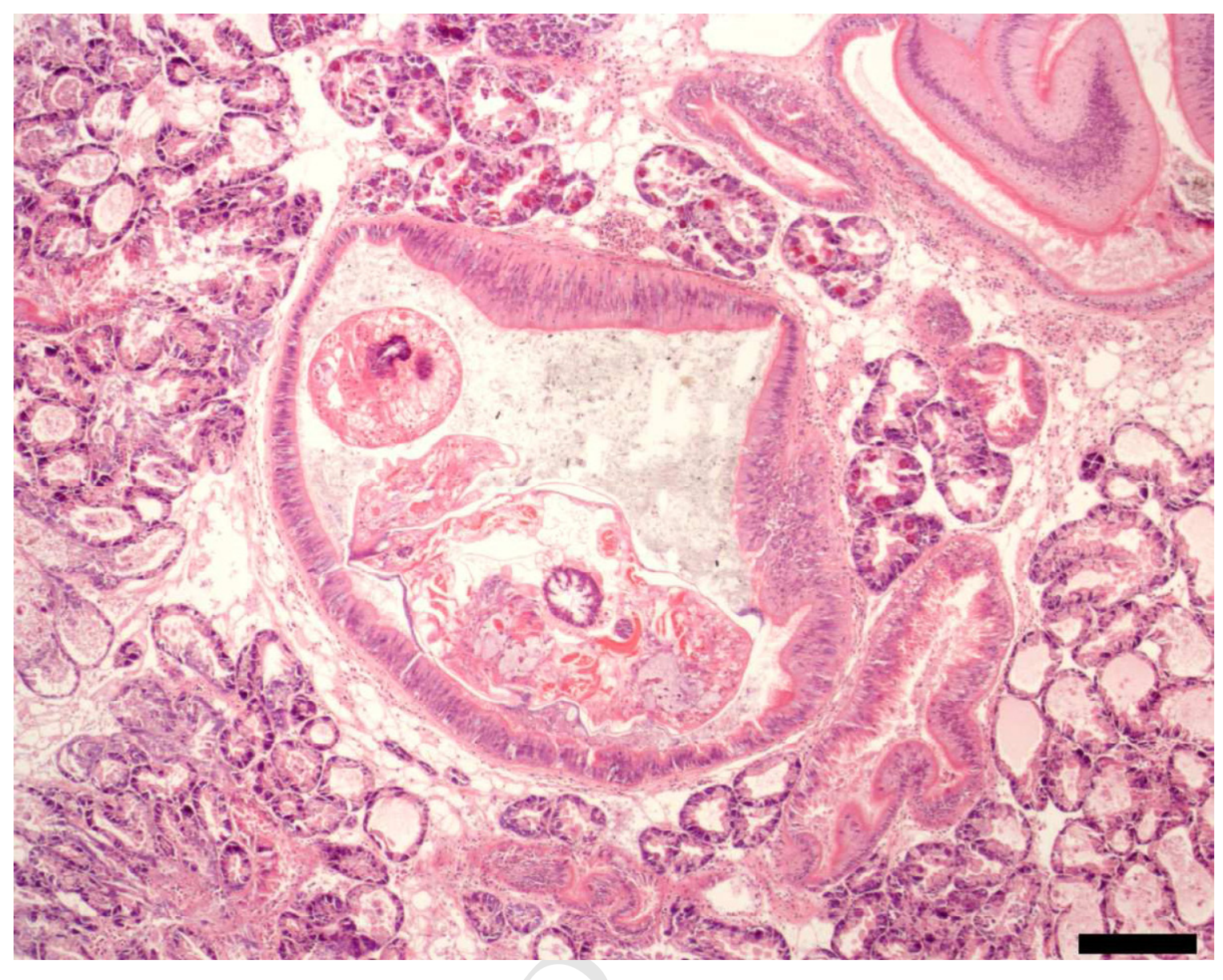




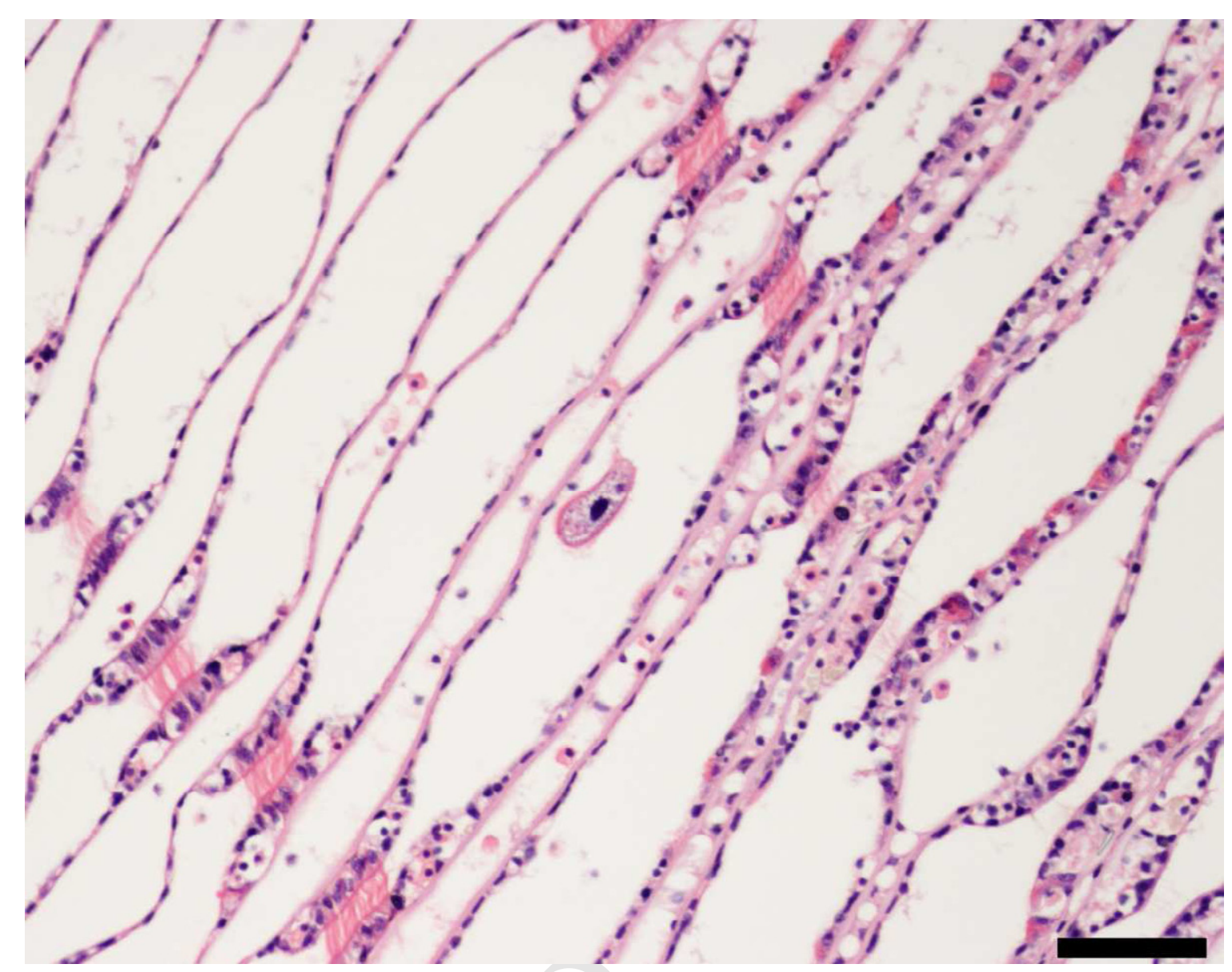




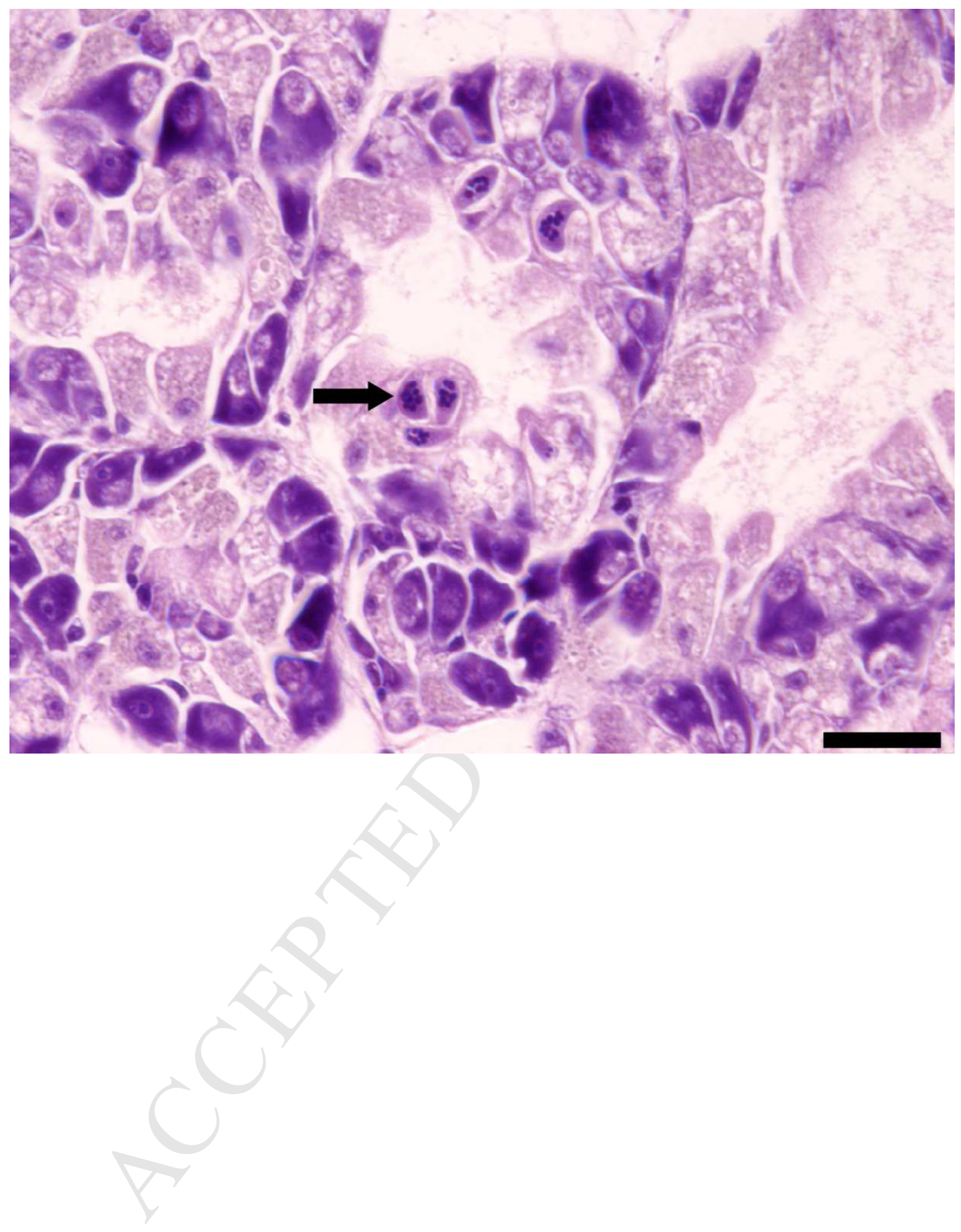




\section{Figure legend}

Figure 1: Map displaying the sampling locations within the Tamar Estuary and Trebarwith Strand.

Figure 2: Histopathology of mussels.

(a) Multiple inflammatory foci (arrow) within the vesicular connective tissue (VCT) of individual mussel from Wilcove. Scale bar $=200 \mu \mathrm{m}$

(b) Small foci of brown cell inflammation situated within the VCT. Scale bar $=50 \mu \mathrm{m}$

(c) Representative micrograph of digestive tubules in the absorptive phase. Scale bar= $100 \mu \mathrm{m}$

(d) Digestive tubules (reconstituting phase) of mussel from Trebawith Strand. Note the reduced epithelial cell height of the digestive tubules. Scale bar $=100 \mu \mathrm{m}$

(e) Lipofuscin accumulation within lysosomes of kidney epithelial cells. Note the presence of small particular and larger aggregations of lipofuscin accumulation. Scale bar $=50 \mu \mathrm{m}$

Figure 3: Histopathology of mussels.

(a) Marteiliosis. Eosinophilic "cell-within-cell" sporocysts clearly identified within the epithelium of the digestive diverticula (arrow). Note co-infection with Rickettsia/Chlamydia-like organisms (arrowhead). Scale bar $=50 \mu \mathrm{m}$

(b) Mytilicola intestinalis located within the stomach. These copepods attach to the stomach wall epithelium using hook attachments. Scale bar $=200 \mu \mathrm{m}$

(c) Ancistrum mytili attached to gill lamellae. Note the presence of pear-shaped body, single large macronucleus and micronuclei. Scale bar $=50 \mu \mathrm{m}$

(d) Ciliophora-like organisms infecting the digestive epithelial cells. Note the presence of multiple parasites within one digestive cell (arrow). Scale bar $=25 \mu \mathrm{m}$. 
Table 1: Grading indices used for the assessment of Kidney Lipofuscin (KL) and Digestive tubule epithelial cell height index.

\title{
KIDNEY LIPOFUSCIN
}

Stage $0 \quad$ Absent

No lipofuscin present within kidney epithelial cells

Stage $1 \quad$ Present

Initial lipofuscin appears faint within epithelial cells

Stage $2 \quad$ Intermediate

A marked increase in the intensity of lipofuscin. $\leq 70 \%$ of cell affected. Most cells display these staining characteristics.

Stage 3 Abundant

All cells contain $\geq 70 \%$ of intense lipofuscin.

\section{DIGESTIVE TUBULE EPITHELIAL CELL HEIGHT}

\author{
Stage $0 \quad$ Normal \\ Tubules nearly occluded, slight atrophy in few tubules
}

Stage $1 \quad$ Slight

Slight atrophy to $50 \%$ normal tubule thickness

Stage $2 \quad$ Intermediate

One half-tubule thickness to significant atrophy. $50-75 \%$ normal tubule thickness

Stage 3 Severe

Extremely thin, severe, most tubules affected. $75 \%+$ normal tubule thickness 


\begin{tabular}{|c|c|c|c|c|c|c|}
\hline & $\begin{array}{l}\text { Index } \\
\text { Range }\end{array}$ & $\begin{array}{l}\text { Neal } \\
\text { Point }\end{array}$ & Wilcove & $\begin{array}{c}\text { Cremyll } \\
\text { Ferry }\end{array}$ & $\begin{array}{c}\text { Whitsand } \\
\text { Bay }\end{array}$ & $\begin{array}{l}\text { Trebarwith } \\
\text { Strand }\end{array}$ \\
\hline Gonadal index ${ }^{*(v)}$ & $0-5$ & 2 & 2 & 3.5 & 4 & 3 \\
\hline Adipogranular (ADG) index* (iii) & $0-5$ & 2 & 2 & 0.5 & 0 & 2 \\
\hline Epithelial cell height index ${ }^{*}(\mathbf{i})$ & $0-3$ & 1 & 1 & 1 & 1 & 2 \\
\hline Kidney lipofuscin index* (vi) & $0-3$ & 1 & 1 & 1 & 1 & 0 \\
\hline \multicolumn{7}{|l|}{${ }^{*}$ Median index } \\
\hline Apoptosis ${ }^{(v)}+$ & & 0.0 & 25.0 & 25.0 & 0.0 & 0.0 \\
\hline Atresia $^{(v)+}$ & & 59.0 & 75.0 & 63.3 & 100.0 & 81.0 \\
\hline Intersex/hermaphrodite ${ }^{(v)}$ & & 0.0 & 0.0 & 0.0 & 0.0 & 0.0 \\
\hline Inflammation (iii) & & 56.7 & 50.0 & 20.0 & 3.3 & 16.7 \\
\hline Granulocytoma $^{(\text {iii) }}$ & & 0.0 & 0.0 & 0.0 & 0.0 & 0.0 \\
\hline Brown cell $(\mathrm{BC})$ inflammation ${ }^{(v)}$ & & 43.3 & 16.7 & 10.0 & 0.0 & 3.3 \\
\hline Brown cell (BC) inflammation (ii) & & 6.7 & 16.7 & 6.7 & 3.3 & 0.0 \\
\hline Brown cell (BC) inflammation (iii) & & 26.7 & 33.3 & 50.0 & 16.7 & 0.0 \\
\hline Pearl formations ${ }^{\text {(iii) }}$ & & 0.0 & 3.3 & 6.7 & 3.3 & 3.3 \\
\hline Lysosomes (i) & & 56.7 & 40.0 & 51.9 & 33.3 & 0.0 \\
\hline Eosinophilic bodies (i) & & 96.7 & 93.3 & 44.4 & 26.7 & 0.0 \\
\hline Degeneration (i) & & 33.3 & 13.3 & 33.3 & 53.3 & 96.7 \\
\hline Rickettsia/Chlamydia-like organisms & & 0.0 & 0.0 & 11.1 & 3.3 & 0.0 \\
\hline Rickettsia/Chlamydia-like organisms ${ }^{(i i)}$ & & 0.0 & 0.0 & 0.0 & 0.0 & 0.0 \\
\hline Ancistrum mytili / other ciliates (ii) & & 6.7 & 20.0 & 26.7 & 0.0 & 0.0 \\
\hline Gregarine $^{(i i)}$ & & 0.0 & 0.0 & 0.0 & 3.3 & 0.0 \\
\hline Digenean metacecarial stages ${ }^{(i i i)}$ & & 0.0 & 0.0 & 6.7 & 6.7 & 0.0 \\
\hline Marteilia sp. ${ }^{(i, i v)}$ & & 0.0 & 6.9 & 31.0 & 0.0 & 0.0 \\
\hline Mytilicola intestinalis (iv) & & 33.3 & 23.3 & 55.2 & 10.0 & 0.0 \\
\hline Steinhausia mytilovum ${ }^{(v)}+$ & & 0.0 & 0.0 & 0.0 & 0.0 & 0.0 \\
\hline Copepod (ii) & & 0.0 & 0.0 & 0.0 & 0.0 & 0.0 \\
\hline Haplospridian (1, ii) & & 0.0 & 0.0 & 0.0 & 0.0 & 0.0 \\
\hline Ciliophora-like organism (i) & & 0.0 & 3.3 & 25.0 & 16.7 & 0.0 \\
\hline Bucephalis ${ }^{(i i, v)}$ & & 0.0 & 0.0 & 0.0 & 0.0 & 0.0 \\
\hline Haemocytic neoplasia ${ }^{(\mathrm{ii}, \mathrm{iij})}$ & & 0.0 & 0.0 & 0.0 & 0.0 & 0.0 \\
\hline Neoplasia ${ }^{(v i)}$ & & 0.0 & 0.0 & 0.0 & 0.0 & 0.0 \\
\hline
\end{tabular}

Table 2: Data for the twenty-seven health index parameters of Mytilus sp.. All data presented as percentage prevalence except where specified. 
Table 3: Logistic regression results showing the relationship between the different study sites and the presence of histopathological indicators. Sites compared to the most upstream site: Neal Point.

Gonad development

Coefficients:

$\begin{array}{lllll} & \text { Estimate Std. } & \text { Error } & z \text { value } & \operatorname{Pr}(>|z|) \\ \text { (Intercept) } & & & & \\ \text { Wilcove } & -0.6931 & 0.387 & -1.790 & 0.074 \\ \text { Cremyll Ferry } & -0.4964 & 0.580 & -0.856 & 0.392 \\ \text { Whitsand Bay } & 1.7047 & 0.566 & 3.011 & 0.003 \\ \text { Trebarwith Strand } & 4.0604 & 1.088 & 3.731 & 0.000 \\ & 2.0794 & 0.599 & 3.474 & 0.001 \\ \text { Inflammation (haemocyte infiltration) } & & & \\ \text { (Intercept) } & 0.268 & 0.368 & 0.728 & 0.467 \\ \text { Wilcove } & -0.268 & 0.519 & -0.517 & 0.605 \\ \text { Cremyll Ferry } & -1.655 & 0.587 & -2.821 & 0.005 \\ \text { Whitsand Bay } & -3.636 & 1.082 & -3.361 & 0.001 \\ \text { Trebarwith Strand } & -1.878 & 0.613 & -3.063 & 0.002 \\ & & & & \\ \text { Brown cell (BC) inflammation } & & & & \\ \text { (Intercept) } & & & & \\ \text { Wilcove } & 0.406 & 0.373 & 1.088 & 0.277 \\ \text { Cremyll Ferry } & -0.539 & 0.522 & -1.032 & 0.302 \\ \text { Whitsand Bay } & -0.272 & 0.522 & -0.521 & 0.603 \\ \text { Trebarwith Strand } & -1.792 & 0.589 & -3.041 & 0.002 \\ & -3.772 & 1.083 & -3.483 & 0.000\end{array}$

